\title{
Kanak Engraved Bamboos: Stories of the Past, Stories of the Present
}

\author{
Roberta Colombo Dougoud
}

\section{Introduction}

A few months after being appointed curator of the Oceanic department at the Musée d'ethnographie de Genève (MEG) in September 1999, I was called in by Dr Louis Necker, the museum director. He took me to a tiny room adjacent to his office, a kind of dark back stage where things were kept out of sight, but not away from memory. With the serious voice of someone leaving his will, he handed me nine large dusty boxes, pronouncing solemnly the following words: 'Dear Madam, I am entrusting to your care these boxes that I myself received when I became director. Inside is the entire work of Marguerite Lobsiger-Dellenbach on the engraved bamboos of New Caledonia. I hope that you will do something. Unfortunately, I myself have not had the time.'

Being the curious woman I am, I eagerly opened the cartons, one after the other. I still remember very clearly how I felt: like a child in front of a box full of toys. As I opened the containers, I was submerged by books, letters, articles, but particularly by dozens and dozens of rolls of tracing paper reproducing bizarre motifs. I woke up from this state of confusion with some vague ideas of a story that might be staged and told through artefacts: a type of object (the engraved bamboos), a woman (Marguerite LobsigerDellenbach, former MEG director), and a people (the Kanak). This was 
the beginning of an extraordinary journey, an intellectual, professional and personal experience which took me from Geneva to Nouméa, from a small country surrounded by mountains to a land cradled by the waves of the ocean, from a past when Kanak artists fixed important events on bamboos, to a present where contemporary artists reconnected with this ancient tradition, renewing it in order to vehicle messages to the new generations.

Some years later, in February 2008, the exhibition Bambous kanak. Une passion de Marguerite Lobsiger-Dellenbach (Kanak bamboos: Marguerite Lobsiger-Dellenbach's great passion) was inaugurated in Geneva, showing the MEG's important collection of Kanak engraved bamboos and the pioneering work of Marguerite Lobsiger-Dellenbach. ${ }^{1}$

\section{Kanak engraved bamboos}

The engraved bamboos (Figure 6) are among the most original works of Kanak art. As the name itself indicates, these are bamboo tubes of varying length and diameter that are engraved or pyrographed. Their entire surface covered with geometric and figurative etchings, they depict with impressive precision and skill many aspects of Kanak life and of the European irruption since the nineteenth century. According to French missionary and anthropologist Maurice Leenhardt (1937: 110), whenever Kanak ventured outside their villages they carried with them an engraved bamboo to ward off danger along the way. The bamboos were sometimes filled with magical herbs for protection. Father Pierre Lambert reported that the old people carried an engraved bamboo like a cane and recounted the exploits and mishaps of their ancestors by referring to the engraved designs (1900: 67-68). To their owners, these objects were at the same time visual prompts, memory aids for speakers in storytelling, devices to remember important events (Vieillard and Deplanche 1862-1863), rollers on which to inscribe their most vivid impressions in order to share them with others (Leenhardt 1937: 111).

1 For a presentation of the exhibition see Cousteau 2008b and Paini 2010. 


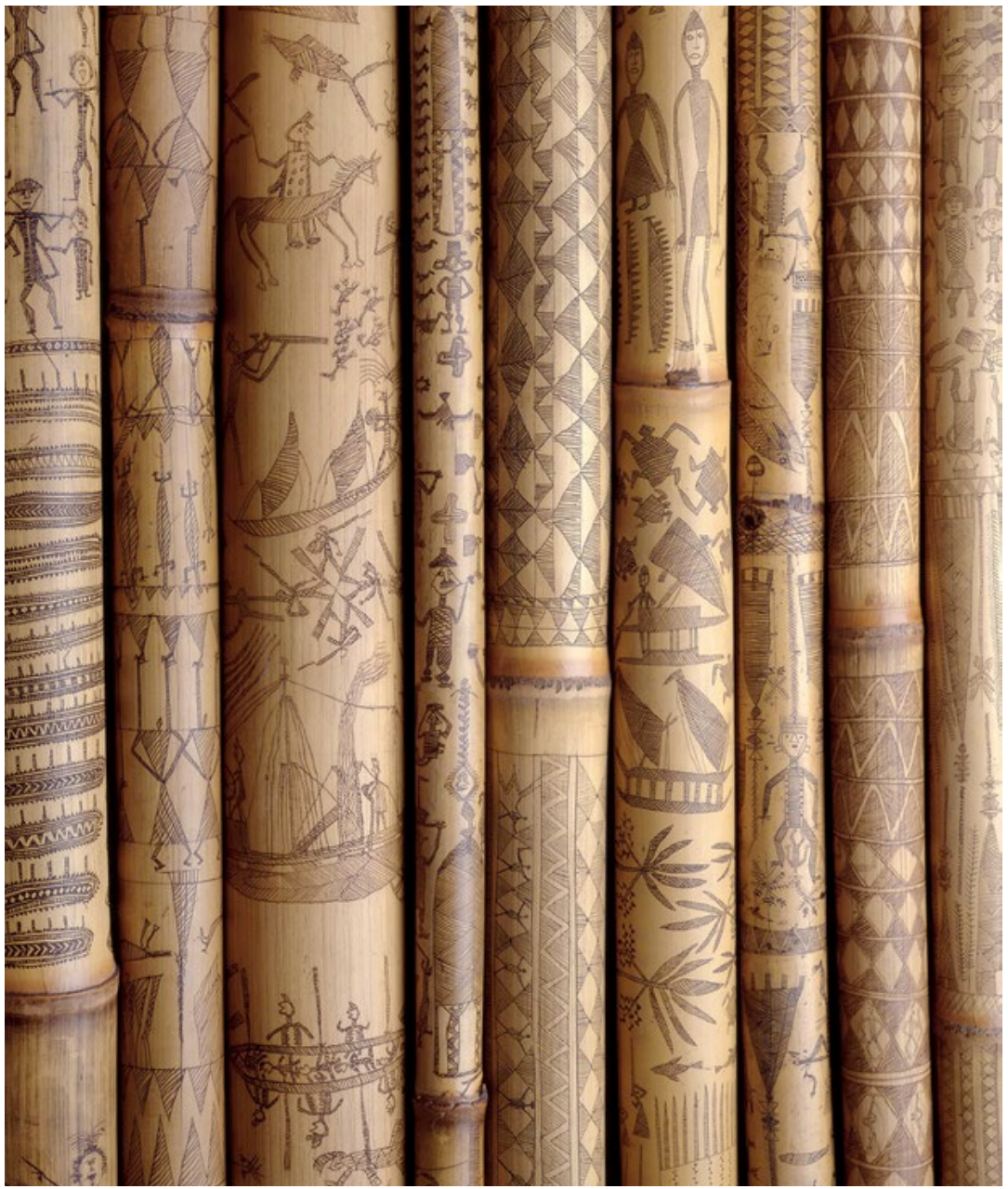

Figure 6. Kanak engraved bamboos

Source. Used with permission of Musée d'ethnographie de Genève @ ( MEG, photographed by Johnathan Watts

In the inventories of museums engraved bamboo have often been registered as chief's staff (bâton de chef), magician's stick (bâton de magicien), walking stick (bâton de voyage) or ceremonial staff (bâton de cérémonie). However, these designations are inexact, because these items were not used as canes and did not belong to a single leader or magician. They were then called 'engraved bamboos' which according to Maurice Leenhardt is the only name given by Kanak (Leenhardt 1937: 109) or, in the Ajië language, kärè e $t \bar{a}$, as reported in the myth 'Les deux sœurs Moaxa' (Leenhardt 1932: 90). 
The bamboo tube was carved while it was still green because, once cut, it begins to dry out very quickly and becomes very difficult to engrave. In some cases it was pyrographed. The etchings were done using quartz crystals, claws of crustaceans, seashells, and more recently metal blades or improvised knives. The tube was then either rubbed with oil extracted from the bankul nut tree or with lampblack, or it was held over a fire, allowing the soot to deposit into the incised parts. In this way, the engraved patterns emerged starkly in black on the clear golden yellow surface of the bamboo.

Collected between 1850 and 1920, the Kanak engraved bamboos date mainly from the nineteenth century. Their production ceased around 1917, the date of one of the major anti-colonial revolts in New Caledonia (Boulay 1993: 27). We do not know the exact causes of this abandonment, but we could suggest the destruction of the chiefs' huts as well as the breakdown of Kanak society under pressure from colonisation and evangelisation. The disappearance of this practice went together with the spread of writing. Paper would have progressively replaced bamboo as a support for memorisation. This would confirm the hypothesis that engraved bamboos' principal function was to fix the most important events in an oral culture (Ohlen 1999: 197). Nevertheless, despite interruption in the practice of engraving bamboos, their graphic expression continues to be an emblematic dimension of Kanak identity to this day.

In order to understand the language of this art form, we must plunge back into the New Caledonia of the nineteenth century. These true 'comic strips' (Métais-Daudré 1973) allow us to reconstruct Kanak material and ceremonial activities as well as their encounter with colonial oppression. Very seldom are Kanak traditional life scenes depicted on their own. In most cases they are represented on the same tube together with motifs inspired by colonisation. In her remarkable work on Kanak engraved bamboos, Carole Ohlen (1987) has classified the incised motifs into two groups: the first includes figurative scenes depicting either Kanak traditional life or the life of Europeans, the second group comprises geometric patterns (Figure 7). ${ }^{2}$ By observing the engravings carefully we can recognise scenes of everyday life: fishing, hunting, yam and taro

2 Carole Ohlen (1987) analysed 84 bamboos, which she numbered and classified by topic. Each item is accompanied by a series of relevant information such as the name given in the register, the museum where the bamboo is stored, its inventory number, the donor's name, the date of entry into the museum, its dimension, a general description, its tracing, and the related bibliography. 
cultivations (Figure 8), villages with the cleared avenue leading to the chief's hut (Figure 9), but also the myths, rituals, pilou, ${ }^{3}$ and mourning (Figure 10). The engravers represented what they saw and, as the main centres of missionary and colonial occupation were close to Kanak villages, they also described colonial life in its numerous aspects: European houses with four-sided roofs, horses mounted or harnessed to a buggy, sailing vessels or steamboats, agricultural and carpentry tools, punitive expeditions, soldiers (Figures 11 and 12) and of course military uniforms. As related by Roger Boulay (1993: 70) the uniforms of the colonial infantry played an important role in Kanak social life. Associated with the military supremacy of the occupant, tunics with stripes were used by the French administrators as insignia of authority, and were offered to the Kanak leaders allied with them.

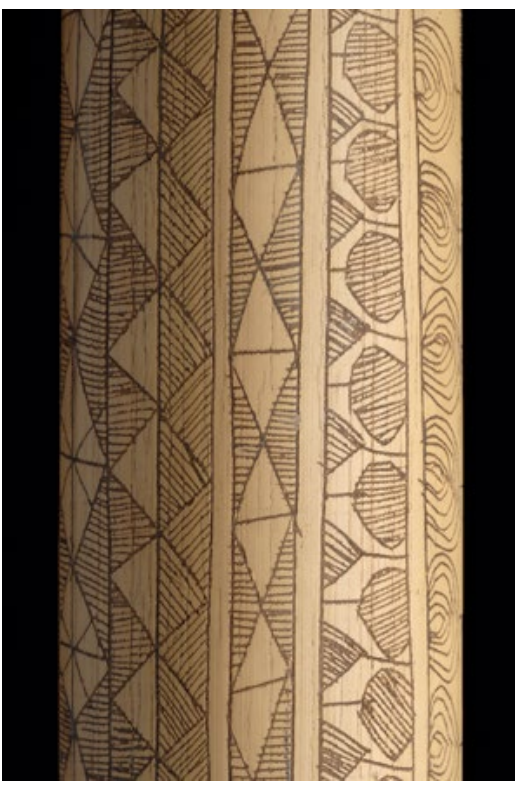

Figure 7. Kanak engraved bamboo with geometric patterns

Source. Used with permission of Musée d'ethnographie de Genève Inv. ETHOC 011682 (C) MEG, photographed by Johnathan Watts

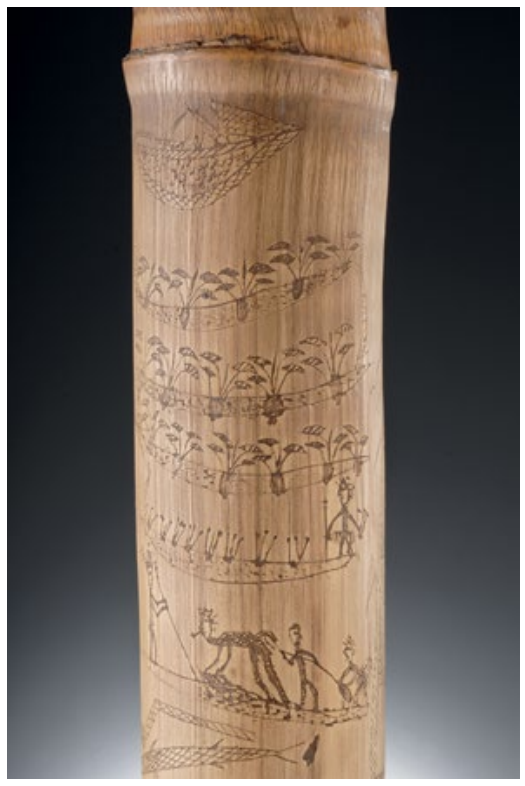

Figure 8. Detail of Kanak engraved bamboo illustrating taro cultivation

Source. Used with permission of Musée d'ethnographie de Genève Inv. ETHOC 020507 (C) MEG, photographed by Johnathan Watts

3 Pilou is a generic term for various Kanak ritualised exchanges and ceremonies. 


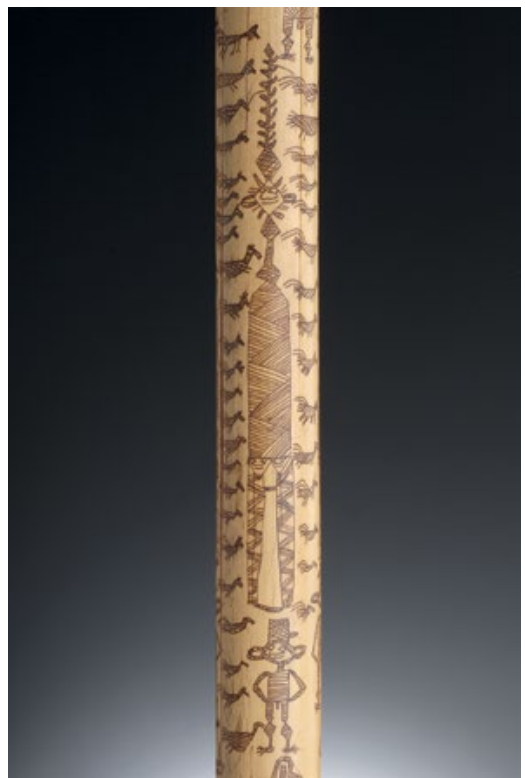

Figure 9. Detail of Kanak engraved bamboo illustrating the chief's hut

Source. Used with permission of Musée d'ethnographie de Genève Inv. ETHOC 012938 @ MEG, photographed by Johnathan Watts

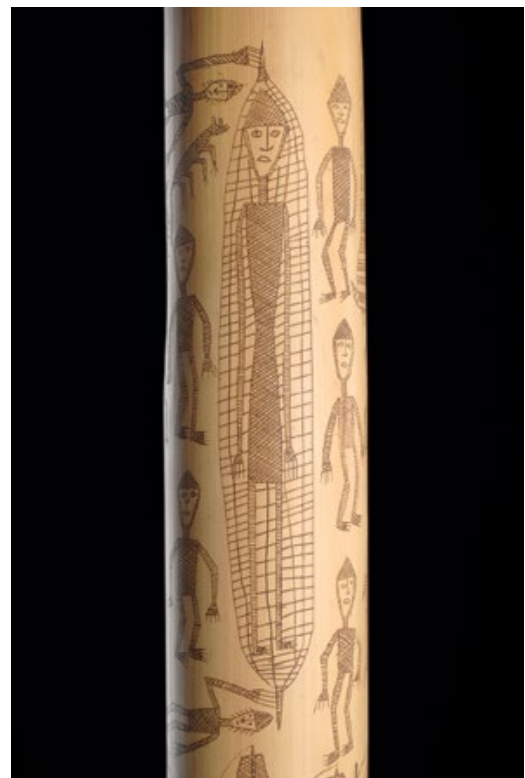

Figure 10. Detail of Kanak engraved bamboo illustrating mourning

Source. Used with permission of Musée d'ethnographie de Genève Inv. ETHOC 022862 (c) MEG, photographed by Johnathan Watts

But engraved bamboos can also be seen as indicators of how the Kanak perceived and judged European colonisation. With extraordinary lucidity and a meticulous attention to detail, the engraver of a bamboo held at MEG has shown the vices introduced by Europeans. This piece constitutes a severe criticism and a mockery of western customs, particularly its immorality, including first of all alcoholism, hitherto unknown in New Caledonia. On the tube, we can see four soldiers in a state of evident drunkenness displaying symbols of their status, bottle, cigar, rifle and money in a parade that we imagine to be noisy and pathetic. Nearby a man is sitting at a table covered with five bottles, one of which is already partly empty (Figure 13). 


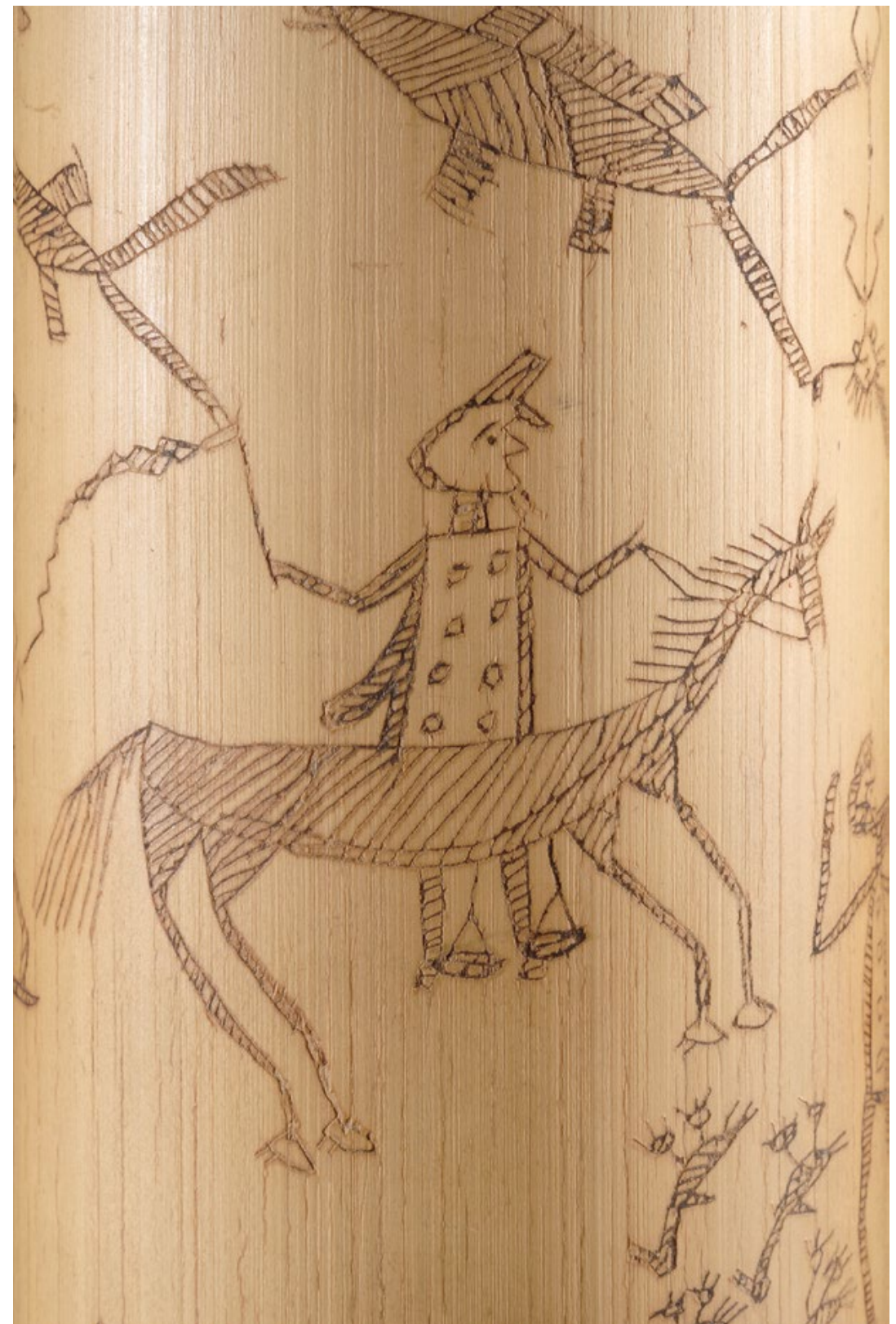

Figure 11. Detail of Kanak engraved bamboo illustrating a soldier on a horse

Source. Used with permission of Musée d'ethnographie de Genève Inv. ETHOC 031759 (C) MEG, photographed by Johnathan Watts 


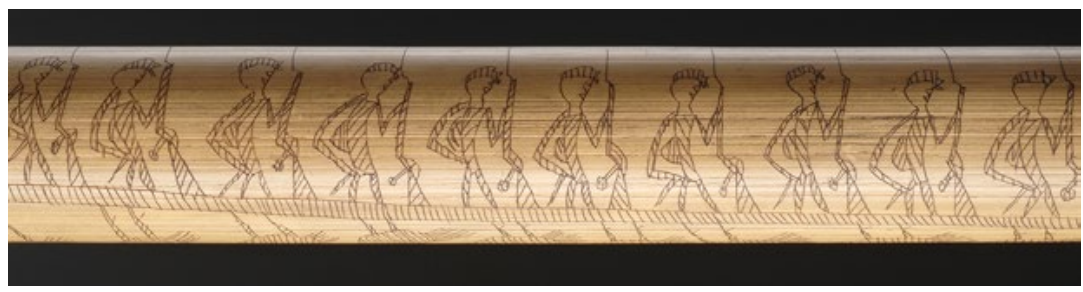

Figure 12. Detail of Kanak engraved bamboo illustrating soldiers with rifles

Source. Used with permission of Musée d'ethnographie de Genève Inv. ETHOC 041749 (C) MEG, photographed by Johnathan Watts

Roger Boulay (1993: 24) raises the question of the origin of engraved bamboos. Could it be an ancient practice, already common before colonisation? Or could the motifs inspired by the European presence be a proof of their late emergence in response to the influence of westerners observed by Kanak in the act of filling their sketchbooks? It is interesting to mention here one of the oldest engraved bamboos, from the Île des Pins. This entirely geometric bamboo, now vanished, was collected in 1875 by Paul Tirat, a naval officer, and exposed in 1888 by the Geographical Society of Paris on the occasion of the commemoration of the centenary of La Pérouse's death. Extremely rare, the engravings were explicated in detail to the acquirer by one of the oldest Kanak chiefs of the Île des Pins, owner of the object. We learn that the entanglement of the engraved geometric figures related one of the first European landings on the island. The zigzag lines indicate the distress of the Kanak at the view of strangers, two sets of diamonds represented the Kanak tribes and the newcomers rushing to assault each other. A series of rifles pointed towards the diamonds symbolising the indigenous groups was placed between these two sets of patterns (Boulay 1993: 20-22). According to historian Georges Pisier (quoted by Ohlen 1987, vol. 1: 25), this story certainly refers to the arrival of La Boussole and of L'Astrolabe, La Pérouse's ships, on the shores of the Île des Pins in 1788. As soon as the crew had disembarked, their many riches and tools excited the envy of natives who attempted to seize them. The Europeans' reaction was immediate and brutal; three Kanak were killed by carbine bullets.

The example of this bamboo along with the old Kanak chief's explanation shows that the geometric patterns are far from being meaningless. This stylised iconographic vocabulary seems to have been a privileged mode of expression before the European arrival fostered a more figurative language. The latter style was apparently already employed, but it was developed 
further under the influence of newcomers and attests to the existence of an ancient tradition of geometric patterns that have gradually lost their significance in favour of figurative scenes (Ohlen 2008: 62). However, very little evidence confirms the existence of engraved bamboos before the colonial period. Therefore, as suggested by Patrice Godin in his article 'Le bambou gravé comme énigme' (2010: 5), the origin and function of engraved bamboos are still shrouded in mystery.

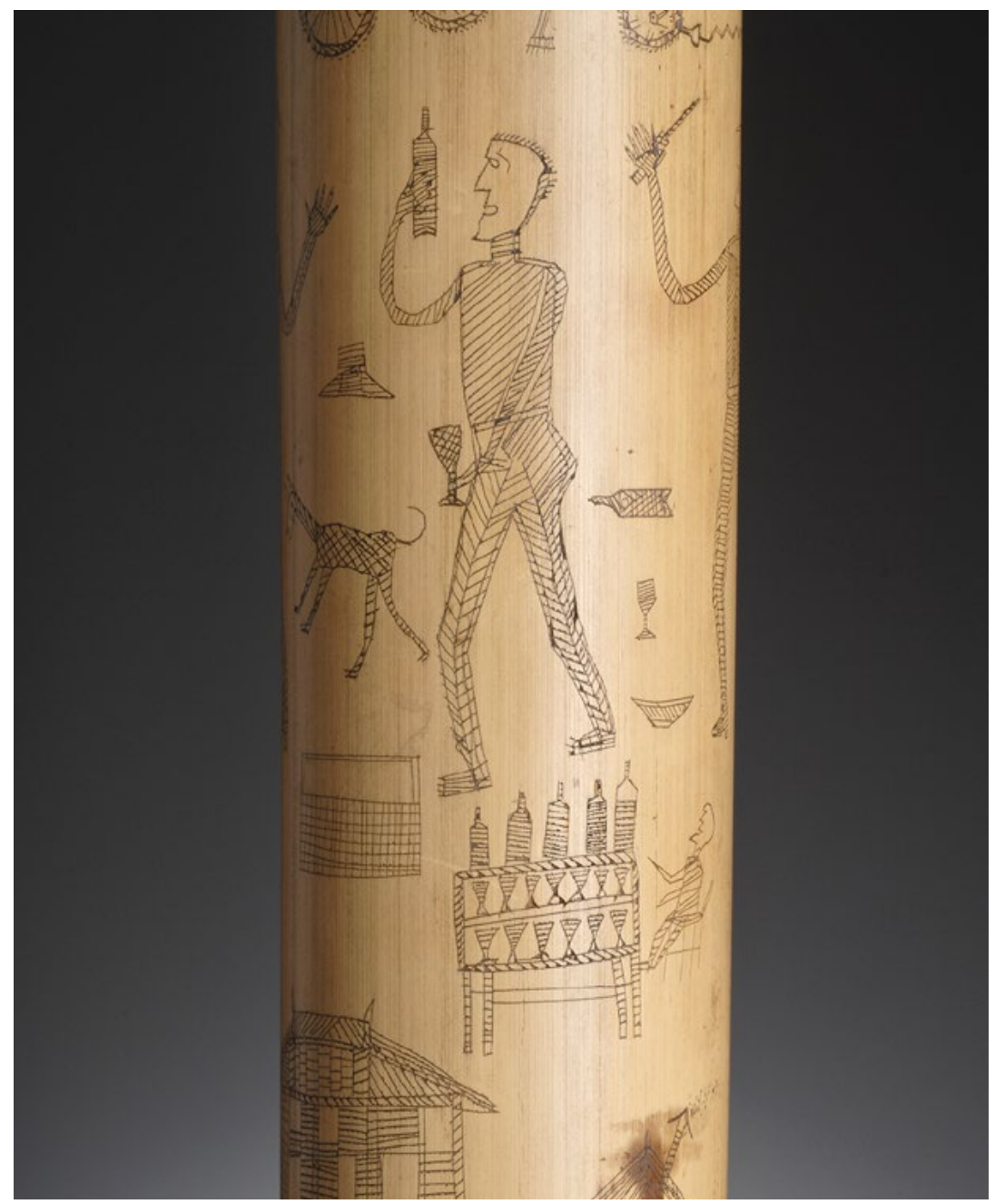

Figure 13. Detail of Kanak engraved bamboo illustrating drunken soldiers

Source. Used with permission of Musée d'ethnographie de Genève Inv. ETHOC 041750 (C) MEG, photographed by Johnathan Watts 


\section{Marguerite Lobsiger-Dellenbach}

It is difficult to calculate the exact number of existing engraved bamboos from New Caledonia, however it is likely that around 300 specimens are stored in museums. If it is predictable that the largest collection is found in France, at the Musée du quai Branly (MQB) with its 64 bamboos, it may appear surprising that the second one, comprising 26 specimens, is in Switzerland, at the MEG. This is due to the fact that Marguerite Lobsiger-Dellenbach, who directed the MEG between 1952 and 1967, had such a strong passion for these objects to the point of becoming a world expert. But who was this woman? ${ }^{4}$

Marguerite-Elisabeth Dellenbach was born in Geneva on 9 July 1905. After training as a milliner and a shorthand typist, she was hired in 1922 as secretary to Professor Eugène Pittard, the MEG's founder. This modest woman became passionately interested in anthropology and decided to continue her studies, obtaining a $\mathrm{PhD}$ and a 'habilitation' after 13 years of hard work. Under Pittard's guidance she oversaw archaeological digs, undertook anthropological measurements and carried out field research in Europe, Western Africa, Nepal, China and the Middle East. Her thirst for discovery and her ambition led her to become first assistant and then deputy director of the MEG from 1947 to 1952. When Eugène Pittard retired, she took over the management of the museum from 1952 to 1967.

During her career, Marguerite Lobsiger-Dellenbach never ceased to explore the diversity of humankind. However, one theme accompanied her throughout her life: the engraved bamboos from New Caledonia. She was captivated by these objects to the point that she became the world's specialist on them, despite the fact that she had never visited New Caledonia. Other researchers had proposed interpretations before hers (Grünewald 1936; Luquet 1926), but she was the one who began their systematic study. Exercising the patience of a saint, alone or with Georges Lobsiger, whom she married in 1936, she copied all the details engraved on the tubes and puzzled out the meanings of the carvings of the MEG collection as well as of bamboos held by many other European museums.

4 For a more detailed biography of Marguerite Lobsiger-Dellenbach, see Colombo Dougoud and Wüscher 2008. 
The two 'Champollion of Kanak writing', as they came to be known, saw in these works an Oceanian version of the Mesoamerican 'painted codex' recording major historical events.

From her earliest writings, Marguerite Lobsiger-Dellenbach distanced herself from a purely decorative analysis or interpretation. She complained that some authors may consider Kanak bamboos only as sketchily engraved, picturesque representations of daily life. For her they were precious ethnographic documents (Dellenbach and Lobsiger 1939: 336), a faithful translation of New Caledonian thought and a lucid vision on the encounter between two worlds. By understanding and interpreting bamboos motifs, it was possible to grasp entire chapters of the material and spiritual life of the Kanak.

When she retired, Marguerite Lobsiger-Dellenbach left the MEG an exceptional series of documents on 93 engraved bamboos. Her dream was to study the bamboos of the entire world and to write a comprehensive work on them.

\section{Bambous kanak, a continuing tradition}

In preparing the exhibition Bambous kanak. Une passion de Marguerite Lobsiger-Dellenbach, we faced some general difficulties and challenges, but in particular two issues were at the centre of our concerns. We wanted to underline that our interpretation of the engraved bamboos comes directly from Marguerite Lobsiger-Dellenbach's research. At the same time, presenting her research offered us an opportunity to explain to our visitors the work of an anthropologist who, through his/her assumptions, hypotheses and interpretations, makes artistic expressions intelligible to us, so that we can better appreciate their aesthetic qualities.

A second relevant issue was linked to contemporaneity. As mentioned above, the production of Kanak engraved bamboos stopped around 1917. Some of them had been collected and kept in the Musée de NouvelleCalédonie (MNC) in Nouméa. In recent years some contemporary artists such as Micheline Néporon, Yvette Bouquet and Paula Boi, inspired by the historical bamboos seen in museums and by publications, have revived this art form in order to express their modern-day concerns. Their remarkable artistic work assumes the same conceptual approach as that of the ancient bamboos. To these artists engraving bamboos does not mean 
looking back but looking ahead, towards the future. In fact, the aim of their project is not the artificial resuscitation of relics from the past, but to express contemporary identity issues. At the same time, the presence of motifs inspired by ancient engraved bamboos in the infrastructures of urban areas-such as the gate of the MNC, the patterns painted on the toll bar north of Nouméa, on the fuselages of Air Calédonie's aircraft as well as on the decorations of its travel agencies-indicate a willingness to reintegrate Kanak cultural elements into a highly westernised urban landscape (Cousteau 2008a: 70). As stated by Diane Cousteau (ibid.: 71), Kanak contemporary artists consider the old engraved bamboos as a source of inspiration, a tradition that they perpetuate, adapt and reactualise.

\section{Micheline Néporon and her bamboos}

During the preparation of the exhibition Bambous kanak. Une passion de Marguerite Lobsiger-Dellenbach, we were able to acquire four bamboos engraved by Micheline Néporon. Born in the Unia tribe, in the Yaté region of New Caledonia on 8 October 1955, Micheline Néporon (Figure 14) is one of the most prominent contemporary Kanak artists, and one of the first Kanak women to devote herself to art. She currently lives in Nouméa where she unremittingly pursues her career as an artist.

As a little girl she wanted to become a nun following the example of Sister Caro, ${ }^{5}$ her mother's sister, but once grown up, she found it difficult to make her own way. Two events were to leave a mark on her and determine the course of her life. In September 1975, she attended the Mélanésia 2000 festival organised by Jean-Marie Tjibaou, the first cultural manifestation in the country that aimed at demonstrating the strength and richness of Kanak culture to the Kanak themselves, while at the same time introducing Europeans to it. Gathering 2,000 Kanak and involving 50,000 spectators, this great celebration marked the beginning of a cultural renaissance for the Kanak people. For the first time Kanak culture was presented as living, as opposed to a culture doomed to disappearance. For Micheline Néporon, as for many other Kanak, Mélanésia 2000 was a revelation.

5 Caroline Newedou (1922-2008), better known as Sister Caro, was an emblematic figure in New Caledonia acknowledged for her engagement in different social activities. 
3. KANAK ENGRAVED BAMBOOS

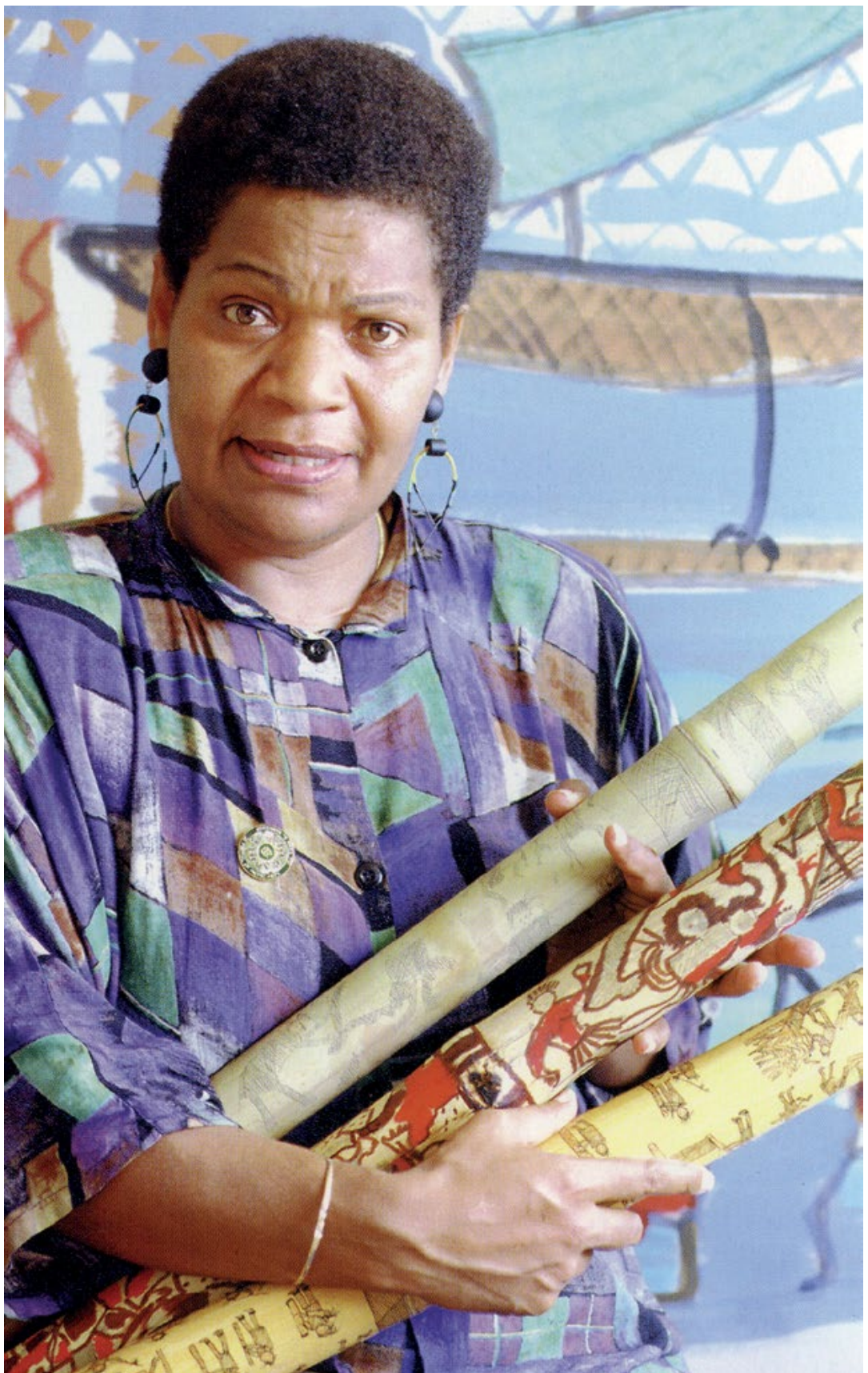

Figure 14. Micheline Néporon

Source. Used with permission of (C) ADCK - centre culturel Jean-Marie Tjibaou, photographed by David Becker 
But another event was going to change the direction of her life. After many odd jobs in catering, house-care and as a lady's companion, she fell ill, a heart disease that forced her to spend two months in hospital. During her convalescence, she kept drawing (Néporon and Bachelot 1991: 71-76), an activity that she has been practising since 1975. She discovered that this was her vocation, and decided to take painting classes. In 1983 she studied with Giovanni Righi at the Academy of Drawing and Painting and 1985 with Jean-Pierre (Jipé) Le Bars at the Office Culturel Scientifique et Technique Canaque in order to learn different techniques (oil, watercolour, Indian ink) and to diversify support. From 1984 to 1985 she ran some art workshops for children at the Centre Récréatif de la Jeunesse and began to exhibit and sell her work. She was noticed by the manager of the gallery Galéria, where her work has been exhibited regularly since 1987 .

From 1985 she began drawing motifs inspired by the engraved bamboos she had first seen at the MNC. She adopted their engraving technique and extended it to other media: canvas, banyan bark, stones and scratchboard using watercolours, acrylics and Indian ink. She freely transposed the traditional technique and drew on different media in order to release the gesture and allow curved lines.

In 1990, she participated in the collective exhibition Ko I Névâ. Sculpteurs et Peintres kanak d'aujourd'hui, organised by the Agency for the Development of Kanak Culture (ADCK). Presented first at Nouméa at the MNC and then travelling throughout New Caledonia for three months, the exhibition was seen by more than 12,000 visitors. The aim was to celebrate and to present a clear picture of the status of contemporary Kanak art, to make an inventory of Kanak painters and sculptors, to present "the soul of our country", conceived by the A.D.C.K. as a survey of the Kanak cultural reality of today' (Togna 1992: 12).

At the end of 1990, Micheline Néporon received a two-year scholarship (Bourse Territoriale de Formation) and left for France to pursue her studies at the Fine Arts Institute in Bordeaux. On the occasion of the exhibition, De jade et de nacre. Patrimoine artistique kanak, ${ }^{6}$ in Paris, an exhibition on

6 The exhibition, De jade et de nacre. Patrimoine artistique kanak was first presented in Nouméa, at the Musée territorial de Nouvelle-Calédonie (today MNC) and then in Paris at the Musée national des arts d'Afrique et d'Océanie. For this occasion, 200 objects were borrowed mostly from the French provincial museums and from other European museums. 
her work, Micheline Neporon, artiste kanak, ${ }^{7}$ was presented at the Musée en Herbe de la Halle Saint-Pierre. In 1992, she continued her training at the Luminy Architectural Fine Arts Institute in Marseille. While in France she had the opportunity to meet many people and see several exhibitions, in a certain way widening her horizons, but she was always aware of the richness of her own cultural heritage. As she writes, 'By immersing myself in Western culture, I felt that I myself had a culture, the Kanak way of thinking and living, a very rich heritage' (Néporon 1993: n.p., my translation).

In 1992, she was part of the New Caledonia delegation to the Festival of Pacific Arts in Rarotonga, in the Cook Islands. The Festival of Pacific Arts is a travelling festival hosted every four years by a different country in Oceania. Following the success of the first festival held at Suva (Fiji) from 6-20 May 1972, it was decided to repeat the experience every four years, each time in a different South Pacific country. Since then, delegations from 27 Pacific Island countries and territories have come together to share and exchange their cultures. Conceived by the Conference of the South Pacific Commission (now the Pacific Community), this was meant as an attempt to combat the erosion of traditional cultural practices. Fearing that the younger generations might be tempted away from their cultural heritage by the introduction of western values, technologies and entertainment, it was established in order to help preserve and develop various local art forms, as well as to provide an occasion for Pacific Islanders to meet, share and celebrate their cultural heritage (Carell 1992; Stevenson 2002).

During the Festival of Pacific Arts in Rarotonga, Micheline Néporon was impressed by the work done by artists from other countries, by the variety of techniques used and by their way of combining their heritage with new technologies, medias and messages, in a word by their capacity to experiment. Back in New Caledonia, she spent a month in Unia with her people, and participated in all the daily and ritual activities such as mourning, weddings and everyday life. As she explained herself (Néporon 1993), this made her want to reproduce all these activities on bamboos. She had already thought of this possibility upon her return from France, and suddenly the penny dropped. She started to revive the traditional technique of engraving bamboos herself-rather than simply painting the motifs inspired by engraved bamboos with Indian ink on paper, as she had been doing since 1985. She restored Kanak bamboos to their primordial

7 A catalogue was published by Micheline Néporon and Roger Boulay (1990). 
function as supports for narratives and memories. For her this was a way of renewing the work of the elders, updating their techniques to express the Kanak's changing world.

For the past 30 years, Micheline Néporon has exhibited widely throughout New Caledonia, France, New Zealand, Australia, Mali, Cook Islands and Vanuatu. Her work is represented in many private and public collections including the Kanak and Oceanian Contemporary Art Collection at the Jean-Marie Tjibaou Cultural Center in Nouméa, the MEG and the MQB. She has developed a personal style that aims to show the coexistence of tradition and modernity and their consequences on the lifestyles of contemporary Kanak. Inspired by models that are now kept in museums, her creations reflect a quest for her roots, but at the same time they testify to her need to look at reality from a contemporary perspective (Gama 2008: 93). She puts the people and culture of New Caledonia today at the centre of her art, and works to reconcile custom with western culture; in her works, scenes of indigenous women with their children and men, dancing in traditional dress, are combined with tokens of modernity and westernisation such as cell phones, radio, motorboats. In the catalogue to a personal exhibition presented at the Jean-Marie Tjibaou Cultural Center, Gîu te mâ, racines de banian, she is descried thus: 'Sensitive and imaginative, she conveys the nostalgia she feels for the world of her childhood, and her desire to help today's young Kanak acquire a better understanding of their own culture, and thus of their identity' (Togna 2004: 4).

Micheline Néporon believes that art is a means of empowerment and emancipation for Kanak women. But at the same time art has a pedagogical capacity, a capacity to convey a message: 'As an artist, I must send a message. Each one of my paintings is a signpost' (cited in Togna 2004: 4). Her works bear witness to the enduring values that underpin Kanak society, but they also denounce the new scourges afflicting the Kanak settlements, the malaise of their young people, the ill effects of alcohol and violence (Tjibaou 2008: 9). She worries about the difficulties faced by young people, apathy towards alcohol, cannabis and traffic accidents.

One of her bamboos conserved at the MEG is particularly representative of her attitude. Engraved in 2005, it has been entitled Halte à l'alcool (Stop to alcohol) by Micheline herself. The story illustrated is a common one, which too often takes place on the roads not only in New Caledonia, but all over the world. It begins in a suburban area as suggested by public housing buildings whose rigid appearance contrasts with the nearby 
bucolic landscape and a traditional hut, reminding us that we are in New Caledonia. We also see large trees, one of which is filled with fruit. A cow is grazing (Figure 15). Below, next to a radio playing at high volume, a young couple is dancing with bottles, the girl is holding one in her mouth (Figure 16). At their feet, empty cans litter the ground. The story continues with a damaged minibus, crashed against a tree (Figure 17). An unconscious person is lying on the ground while someone is trying to assist him. Two rescuers are rushing with a stretcher while a policeman is already on site (Figure 18). But this drama is not isolated. Another vehicle has just had an accident by an embankment. Its distraught occupants are getting out while a rescue helicopter approaches.

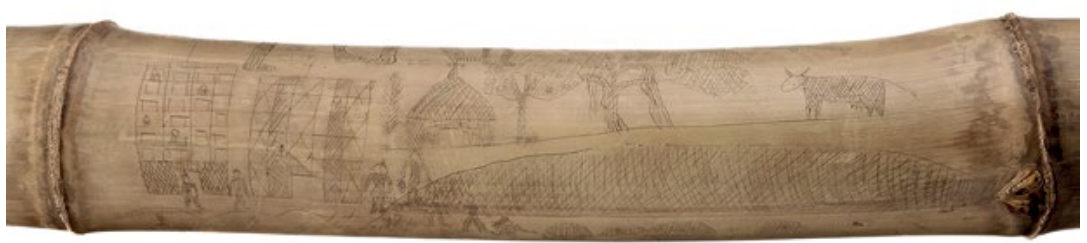

Figure 15. Halte à l'alcool (Stop to alcohol). Detail of Kanak engraved bamboo by Micheline Néporon

Source. Used with permission of Musée d'ethnographie de Genève Inv. ETHOC 064815 (C) MEG, photographed by Johnathan Watts

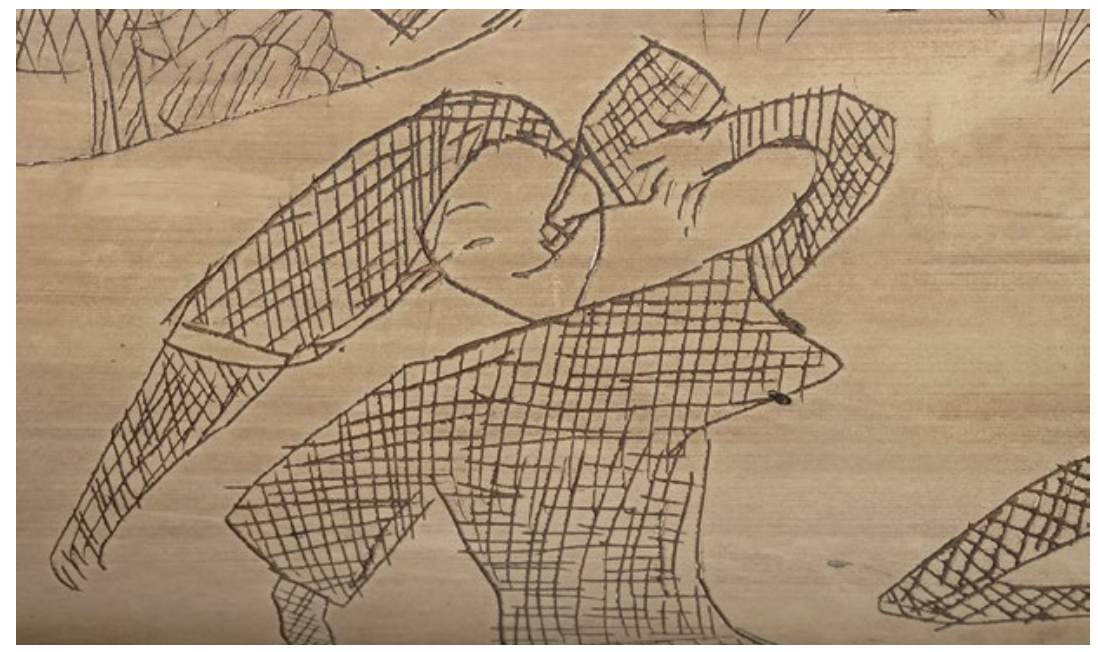

Figure 16. A girl drinking from a bottle of alcohol. Detail of Kanak engraved bamboo by Micheline Néporon

Source. Used with permission of Musée d'ethnographie de Genève Inv. ETHOC 064815 (C) MEG, photographed by Johnathan Watts 


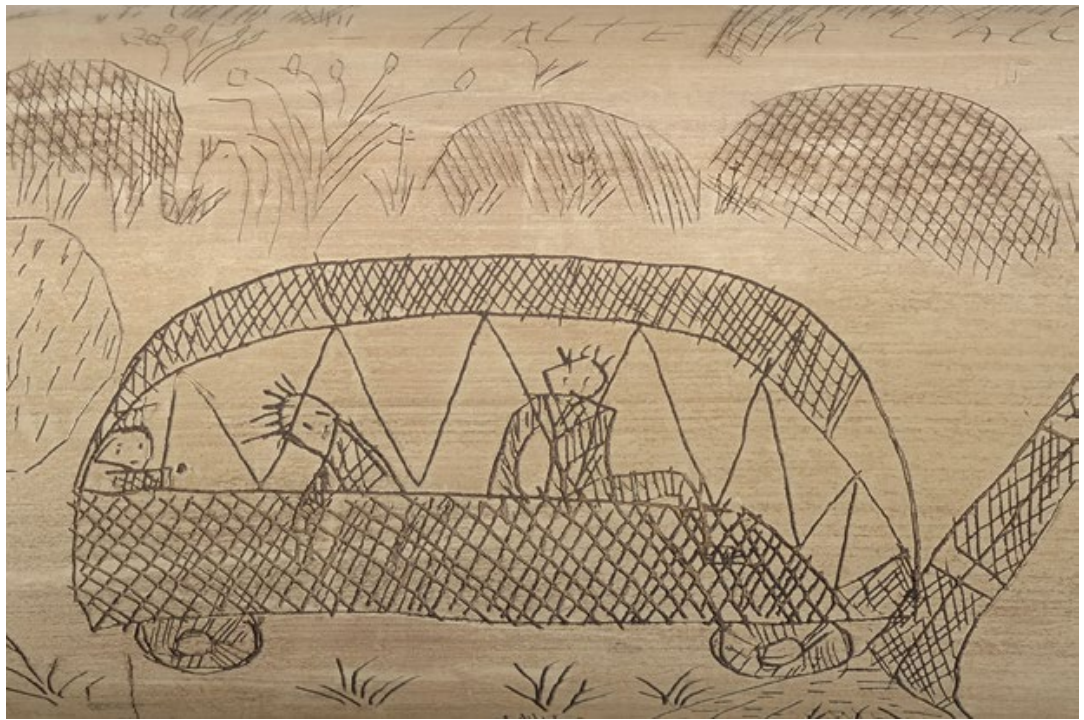

Figure 17. A damaged minibus, crashed into a tree. Detail of Kanak engraved bamboo by Micheline Néporon

Source. Used with permission of Musée d'ethnographie de Genève Inv. ETHOC 064815 (C) MEG, photographed by Johnathan Watts

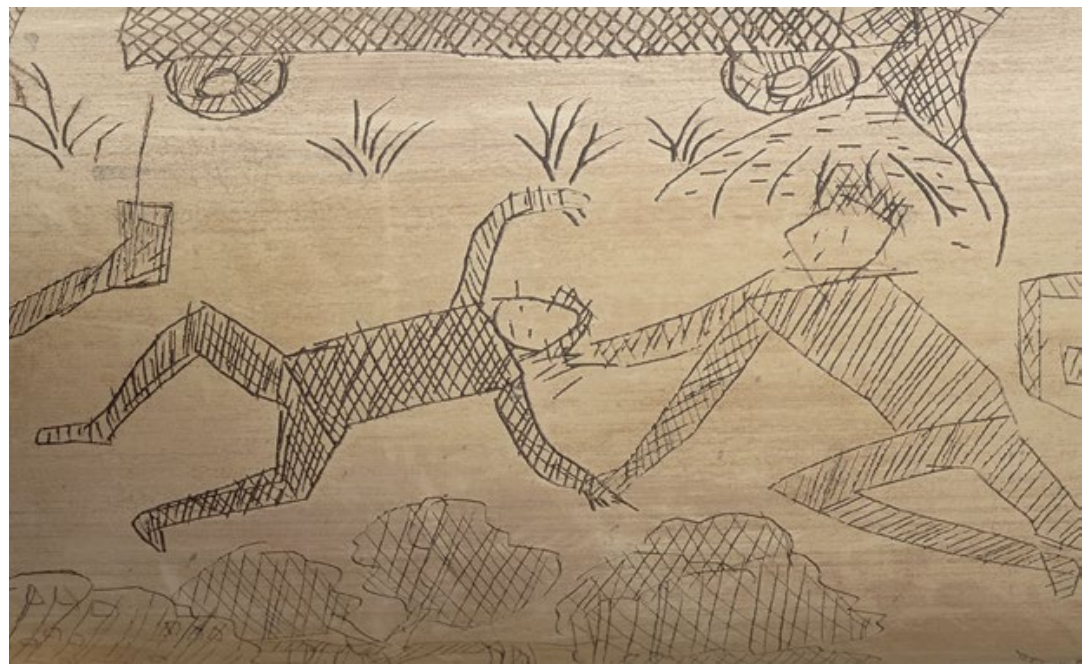

Figure 18. An unconscious person lying on the ground. Detail of Kanak engraved bamboo by Micheline Néporon

Source. Used with permission of Musée d'ethnographie de Genève MEG Inv. ETHOC 064815 @ $\mathrm{MEG}$, photographed by Johnathan Watts 


\section{From Geneva to Nouméa and back}

It was between 1840 and 1890 , during the so-called 'Museum Period' (Sturtevant 1969) that most ethnographic collections were built up with the purpose of gathering the material heritage of peoples of the colonised countries who were considered to be dying out. Museums as cultural institutions had the task of safeguarding their cultural expressions for the future. Collecting was a one-way relationship deriving from a principle of colonial inequality: artefacts and information about their origin, production, function and use went from people all over the world to the museums. Their curatorial and institutional authority consolidated the knowledge (Peers and Brown 2003: 1). Over the last 40 years, this relationship has deeply changed. Not only physical ownership of the objects but also the right of representing their meaning have become issues of contention (Stocking 1985). Shifts towards a more two-way type of relationship can be observed. Indigenous interests, values and perspectives are increasingly taken into account by museum curators and some source communities have started to cooperate with them in the context of the management of their ethnographic collections. In this changing power relation, museums are no longer the sole voice of authority and new paradigms for a critic and reflexive museography are discussed (Karp and Lavine 1991). Aware of the political, identity, cultural and social stakes involved in the representation of their culture in a museum, source communities wish to be no longer merely spectators, but active players, who claim the right to speak about themselves and their heritage. It is in this context of confrontation that the demands for retreat from display or for repatriation of human remains and of sensible objects must be understood (Edwards, Gosden and Phillips 2006; Fforde, Hubert and Turnbull 2002).

Noteworthy and inspiring is the perspective developed in New Caledonia which considers the Kanak objects stored abroad as ambassadors of Kanak culture. In the 1980s, at the bequest of Jean-Marie Tjibaou, French anthropologist Roger Boulay undertook an extensive project to locate the Kanak collections in Europe and metropolitan France. The aim was not to carry out an exhaustive inventory of what is known as 'dispersed Kanak heritage' but to build a database of the major museums holding Kanak artistic heritage (Boulay 2006: 36). This project led to the exhibition De jade et de nacre. Patrimoine artistique kanak first presented in Nouméa at the Musée Territorial de Nouvelle Calédonie from March to May 1990 and then in Paris at the Musée National des Arts Africains et Océaniens 
from October to December of the same year. ${ }^{8}$ In order to prepare for the temporary return of dispersed heritage to New Caledonia, Roger Boulay and Emmanuel Kasarhérou, the exhibition curators, undertook a series of visits to different communities so that they could not only explain the exhibition aims and contents, but also understand people's expectations and anticipate their reactions. Emmanuel Kasarhérou (2005: 286) was willing to display a gwâ mie, a head of Kanak currency, held at the Musée d'ethnographie de Neuchâtel (MEN) that had been donated in 1910 by Maurice Leenhardt. He had received this extraordinary piece from the Misikoéo (Miyikwéö) clan, Kasarhérou's clan. When elders from Kasarhérou's family saw the object they were astonished by its artistic and cultural value. They did not ask for the final return of the object to New Caledonia because they did not know the reasons, or the conditions in which it had been offered. Given its symbolic importance, the elders thought it had been given to Maurice Leenhardt probably following a conversion to Christianity. They declared that they could not go back on a given word. Rather, they were grateful to Switzerland to have kept the gwâ mie and to have allowed them to see it. In the discussion between the Agency for the Development of Kanak Culture and the elders, it was determined not to actively seek the return of any of these objects, many of which have spent up to 150 years away from New Caledonia (and which, according to traditional beliefs, may be dangerous in cases in which the conditions of acquisition are unknown). As Emmanuel Kasarhérou explained in an interview to Anna Paini and Adriano Favole in 2007, these objects had indisputably left; nevertheless, they should not be considered as an absence, as something that was missing. They were far away because they had been sent in order to accomplish a specific task, that of becoming messengers, ambassadors who create connections and open paths. Having travelled and been exposed abroad, these objects should be considered as 'ambassadors' of Kanak culture, employed to let the rest of the world know that Kanak exist (Paini and Favole 2007: 10-11).

I think that these reflections will help us to understand the spirit of the exhibitions on the Kanak engraved bamboos held in 2008 at the MEG, but also the collaboration with the MNC, which gave birth to a more elaborate exhibition on engraved bamboos. Entre-vues sur Bambous

8 More than 20 years later the extensive and comprehensive research on the dispersed kanak heritage led to a major exhibition Kanak, l'Art est une Parole presented at the MQB from October 2013 to January 2014 and then in a reduced version at the Jean-Marie Tjibaou Cultural Center in Nouméa from March to June 2014. 
kanak, de Genève à Nouméa opened in Nouméa in March 2010. ${ }^{9}$ The title proposed by the MNC team underlines that it is an encounter, a dialogue, a collaboration around Kanak bamboos, a sharing of gazes and knowledge. And, indeed, the MNC didn't just host MEG's exhibition; together, in partnership, we created a new exhibition.

Entre-vues sur Bambous kanak, de Genève à Nouméa was a great chance for curators to experiment with forms of collaboration and knowledge sharing, for people from New Caledonia to see for the first time such a rich presentation of engraved bamboos, and also for the MEG bamboos, historical and contemporary, to acquire new strength and power, to revitalise themselves back home before continuing to play their role of ambassadors of Kanak existence.

\section{References}

Boulay, Roger. 2006. 'Les collections océaniennes dans les collections publiques françaises: état des lieux’, Mwà Véé 54: 34-44.

1993. Le bambou gravé kanak. Marseille: Éditions Parenthèses / Agence de développement de la culture kanak.

Carell, Victor. 1992. 'The purpose, origin and future of festivals of Pacific arts'. Pacific Arts 5: 1-5.

Colombo Dougoud, Roberta and Lorin Wüscher. 2008. 'Marguerite Lobsiger-Dellenbach et les bambous kanak: une femme, une passion, un peuple'. In Bambous kanak. Une passion de Marguerite LobsigerDellenbach, ed. Roberta Colombo Dougoud, pp. 17-35. Gollion and Genève: Infolio and Musée d'ethnographie de Genève.

Cousteau, Diane. 2008a. 'Les bambous gravés dans la Nouvelle-Calédonie contemporaine'. In Bambous kanak. Une passion de Marguerite LobsigerDellenbach, ed. Roberta Colombo Dougoud, pp. 69-79. Gollion and Genève: Infolio and Musée d'ethnographie de Genève.

——. 2008b. 'Scénographie et sensorialité'. Totem 51: 8-9.

9 For a presentation of the exhibition, see Paini 2010. 
Dellenbach, Marguerite and Georges Lobsiger. 1939. 'Quelques scènes de la vie sociale, religieuse et matérielle des Néo-Calédoniens, gravées sur bambou'. Archives suisse d'Anthropologie générale VIII(3-4): 336-50.

Edwards, Elizabeth, Chris Gosden and Ruth Phillips (eds). 2006. Sensible Objects: Colonialism, Museums and Material Culture. London: Berg Publishers.

Fforde, Cressida, Jane Hubert and Paul Turnbull (eds). 2002. The Dead and their Possessions: Repatriation in Principle, Policy and Practice. London and New York: Routledge.

Gama, Henri. 2008. 'Micheline Néporon, la tresseuse d'histoires'. In Bambous kanak. Une passion de Marguerite Lobsiger-Dellenbach, ed. Roberta Colombo Dougoud, pp. 91-93. Gollion et Genève: Infolio et Musée d'ethnographie de Genève.

Godin, Patrice. 2010. 'Le bambou gravé comme énigme'. In Entre-vues sur Bambous kanak, de Genève à Nouméa, ed. Solange Néaoutyine, p. 5. Éditions du musée de Nouvelle-Calédonie, Nouméa: Service des Musées et du Patrimoine.

Grünewald, Roland. 1936. 'Trois bambous gravés néo-calédoniens inédits'. L'Anthropologie T. 46: 633-40.

Karp, Ivan and Steven D. Lavine (eds). 1991. Exhibiting Cultures. The Poetics and Politics of Museum Display. Washington D.C. and London: Smithsonian Institution Press.

Kasarhérou, Emmanuel. 2005. 'L'ambassadeur du brouillard blanc'. In Cent ans d'ethnographie sur la colline de Saint-Nicolas, ed. MarcOlivier Gonseth, Jacques Hainard and Roland Kaehr, pp. 285-86. Neuchâtel, Musée d'ethnographie.

Lambert, Pierre. 1900. Mours et superstitions des Néo-Calédoniens. Nouméa: Nouvelle Imprimerie Nouméenne.

Leenhardt, Maurice. 1937. Gens de la grande terre. Nouvelle-Calédonie. Paris: Gallimard.

—. 1932. Documents néo-calédoniens. Paris: Institut d'Ethnologie. 
Luquet, Georges-Henri. 1926. L'art Néo-Calédonien. Documents recueillis par Marius Archambault, directeur du service des postes et télégraphes en Nouvelle-Calédonie. Paris: Institut d'Ethnologie.

Métais-Daudré, Éliane. 1973. Les Bandes dessinées des Canaques. Paris: Mouton.

Néporon, Micheline. 1993. Geïra. Le lieu d’où je suis. Nouméa: Agence de développement de la culture kanak.

Néporon, Micheline and Suzanne Bachelot. 1991. 'Kungô Bré: 'Les racines de l'arbre nouveau'. Paroles de femmes kanak de la tribu d'Unia (Yaté)'. Nouméa: Agence de développement de la culture kanak.

Néporon, Micheline and Roger Boulay. 1990. Micheline Néporon, artiste kanak. Paris: Halle Saint-Pierre.

Ohlen, Carole. 2008. 'Lart traditionnel du bambou gravé kanak'. In Bambous kanak. Une passion de Marguerite Lobsiger-Dellenbach, ed. Roberta Colombo Dougoud, pp. 47-66. Gollion and Genève: Infolio and Musée d'ethnographie de Genève.

—_. 1999. 'Les bambous gravés'. In Chroniques du pays kanak, ed. Orso Filippi, pp. 196-207. Nouméa: Planète Mémo, III, éd.

—_. 1987. Iconographie des bambous gravés de Nouvelle-Calédonie. Objets et "décors", vols 1 et 2, Mémoire de Maîtrise en Esthétique et Sciences de l'Art, Paris I, Paris: Panthéon-Sorbonne.

Paini, Anna. 2010. 'Bambù kanak: objets de relation. Da Ginevra a Nouméa con una postilla genovese'. Antropologia Museale 27: 60-64.

Paini, Anna and Adriano Favole. 2007. Intervista a Emmanuel Kasarhérou'. Antropologia Museale 5(16): 7-16.

Peers, Laura and Alison K. Brown (eds). 2003. Museums and Source Communities: A Routledge Reader. New York: Routledge.

Stevenson, Karen. 2002. 'The Festival of Pacific Arts: Its past, its future'. Pacific Arts 25: 31-40.

Stocking, George W. Jr. (ed.). 1985. Objects and Others: Essays on Museums and Material Culture. Madison: University of Wisconsin Press. 
Sturtevant, William C. 1969. 'Does anthropology need museums?' Proceedings of the Biological Society of Washington 82: 619-50.

Tjibaou, Marie-Claude. 2008. 'Avant-propos'. In Bambous kanak. Une passion de Marguerite Lobsiger-Dellenbach, ed. Roberta Colombo Dougoud, pp. 7-9. Gollion and Genève: Infolio and Musée d'ethnographie de Genève.

Togna, Octave. 1992. 'The kanak fiber. La fibre kanak'. In Sculpteurs et Peintres Kanak contemporains. Ko i Névâ, ed. Cristina D. Chaplain, pp. 12-13. Nouméa: Agence de développement de la culture kanak.

Togna, Octave (ed.). 2004. Gûu te mâ, racines de banian. Banyan Roots. Micheline Néporon. Nouméa: Agence de développement de la culture kanak.

Vieillard, Eugène and Émile Deplanche. 1862-1863. 'Essais sur la Nouvelle-Calédonie'. Revue Maritime et Coloniale VII, Paris. 
This text is taken from Tides of Innovation in Oceania: Value, materiality and place, edited by Elisabetta Gnecchi-Ruscone and Anna Paini, published 2017 by ANU Press, The Australian National University,

Canberra, Australia. 